\title{
The Relationship among Receptive Vocabulary, Non-word Repetition, and Quick Incidental Learning in Preschoolers with and without Delay in Vocabulary Development
}

\author{
Yoonhee Yang, Dongsun Yim, Shinyoung Kim, Jiyun Han \\ Department of Communication Disorders, Ewha Womans University, Seoul, Korea
}

\author{
Correspondence: Dongsun Yim, $\mathrm{PhD}$ \\ Department of Communication Disorders, Ewha \\ Womans University, 52 Ewhayeodae-gil, \\ Seodaemun-gu, Seoul 120-750, Korea \\ Tel: $+82-2-3277-2120$ \\ Fax: $+82-2-3277-2122$ \\ E-mail: sunyim@ewha.ac.kr
}

Received: October 5, 2013

Revised: November 14, 2013

Accepted: December 10, 2013

This work was supported by BK21plus project by the Korean Government.

\begin{abstract}
Objectives: The present study investigated whether children with normal language (NL) and children with delay in vocabulary development (VD) show difference in performance on non-word repetition and quick incidental learning (QUIL), whether these factors correlate with one another, and whether these factors could predict children's receptive vocabulary. Methods: The study included children between 2 to 6 years of age, $19 \mathrm{NL}$ and $19 \mathrm{VD}$. The experiments consisted of two tasks: non-word repetition to measure phonological memory, and QUIL to measure vocabulary learning ability. We compared group performances on each task. We also investigated correlations among factors and predictors. Results: The results were as followed. There were significant differences between two groups on all two tasks showing that children with VD performed significantly lower than children with NL. In the VD group, receptive vocabulary correlated only with the non-word repetition task, whereas receptive vocabulary correlated with both non-word repetition and QUIL tasks in the NL group. The strongest factor which predicted children's receptive vocabulary was QUIL in NL group, whereas non-word repetition predicted VD group's receptive vocabulary the most. Conclusion: The results show that implicit learning ability could be the important factor only in young NL group when they learn receptive vocabularies. On the other hand, phonological short-term memory promotes receptive vocabulary learning in VD group. It indicates that children with VD inefficiently learn vocabularies compared to NL children, and if children with VD could facilitate implicit learning ability, it could result in effective vocabulary learning.
\end{abstract}

Keywords: QUIL, Vocabulary learning, Non-word repetition, Phonological memory, Preschool children
어휘 습득은 의사소통의 수단이 되는 언어체계를 확장시키는 과 정이자, 학업적 성취 및 나아가 사회적 성공에 영향을 미치는 인지 적 기술이기도 하다. 인간의 발달과 사회적 성취에 있어서 어휘 습 득이 가지는 중요성은 이미 많은 연구들에서 검토되었으며(Gathercole, \& Baddeley, 1990), 어휘 습득을 가능하게 하고 그것을 예측 할 수 있는 기제가 무엇인지 밝히기 위한 연구도 뒤를 이어 다각적 으로 진행되어 왔다(Mcbride-Chang et al., 2005; Michas \& Henry,
1994; Penno, Wilkinson, \& Moore, 2002).

어휘 습득의 기초 기술로는 '빠른 연결(fast mapping)'을 들 수 있 는데(Carey \& Bartlett, 1978), 이는 새로운 어휘를 단 한 번 또는 최 소한으로 노출했을 때 그 어휘가 지칭하는 대상을 빠르게 연결시 켜 새로운 어휘를 빠르게 학습할 수 있도록 돕는 인지적 기제를 말 한다. 즉, 이러한 ‘빠른 연결' 능력으로 인하여 아동은 새로운 어휘 의 음운적, 구문적, 의미적 표상을 빠르게 형성할 수 있고, 이러한 
능력은 아동이 짧은 시간에 많은 어휘를 습득하게 되는 현상을 설 명할 수 있다(Dollaghan, 1985). 많은 연구자들은 만 2세경 '빠른 연결’ 능력이 나타나며, 이 기술은 약 18 개월부터 시작되는 아동들 의 어휘 학습에 가속도를 붙이는 데 중요한 공헌을 한다고 보았다

(Golinkoff, Hirsh-Pasek, Bailey, \& Wenger, 1992; Gray, 2006).

빠른 우연학습(quick incidental learning, QUIL)은 아동의 '빠른 연결' 능력을 평가할 수 있는 과제로(Rice, Buhr, \& Nemeth, 1990), 일반적으로 아동에게 여러 개의 새로운 어휘들을 삽입하여 만든 이야기를 영상으로 보여주고, 시청이 끝난 후 아동이 영상을 보는 동안에 접한 새로운 어휘를 습득했는지를 평가하는 방식으로 구 성된다(Oetting, Rice, \& Swank, 1995). 빠른 우연학습 과제는 지시 어와 참조물의 직접적·명시적인 연결로 어휘를 학습하는 방식이 아닌, 아동에게 아무런 단서 없이 이야기를 통해 새로운 어휘를 우 연히 노출시킴으로써 아동이 어휘를 암묵적으로 학습하도록 설계 되었으며, 이는 발달단계에서 아동이 어휘를 습득하는 자연스러운 언어 환경과 유사하다는 특징을 지닌다. 빠른 우연학습 과제는 여 러 연구에서 다양한 형태로 변형되어 아동의 어휘 습득 능력을 평 가하는 데에 사용되었으며, 선행 연구에서는, 일반 아동과 단순언 어장애 아동의 빠른 우연학습 수행력을 비교함으로써 단순언어장 애 아동의 빠른 우연학습 수행력이 일반 아동에 비하여 유의하게 낮음을 밝힌 연구 결과가 있다(Bishop, 1992; Leonard, 1989). 이는 ‘빠른 연결’을 다루는 ‘빠른 우연학습’ 과제가 아동의 어휘 능력과 관계가 있음을 보여주는 결과라 할 수 있다.

한편, Howell 등(2005)의 연구에서는 아동들이 어휘를 습득할 때 도움이 되는 의미적 정보를 사용하면 새로운 어휘를 학습하는 데 도움이 될 수 있을 것으로 보았다. 만약 이러한 의미정보가 어휘 습득에 도움이 된다면, 어휘발달에 지체를 보이는 아동들은 의미 자질을 어휘와 빠르게 연결하는 능력이 부족하기 때문에 불이익을 받을 수 있으며(Alt, Plante, \& Creusere, 2004), 일반 또래 아동에 비 해 의미적 부호화 능력이 제한되어 있기에(Kail, Hale, Leonard, \& Nippold, 1984; McGregor, Newman, Reilly, \& Capone, 2002) 이 또 한 어휘학습에 어려움을 가져올 수 있다. 이러한 의미자질의 빠른 연결은 또한 비단어 따라말하기와도 유의한 상관관계가 있다고 밝 혔다(Alt \& Plante, 2006). 음운체계는 어휘 및 의미 수행과 연결되 며(Storkel, 2001), 어휘, 의미, 음운 처리는 일반 아동의 효율적인 어 휘 학습 결과로 귀결된다(Alt \& Plante, 2006). 새로운 단어 혹은 비 단어를 처리하는 것은 어휘적, 음운적 정보 모두에 의존할 수 있기 때문이다(Storkel \& Morrisette, 2002). Nash와 Donaldson (2005) 의 연구에서는 어휘가 부족한 아동들이 어휘 학습의 음운적 양상 과 같이 의미에서의 어려움을 지닌다고 밝혔다. 또한, 이 아이들은
명시적 학습 문맥에서보다 이야기 문맥 안에서 새로운 어휘를 학 습하는 것에 더 어려움을 보이는 것을 발견하였다.

$\operatorname{Kim}$ (2005)은 만 4-5.5세의 단순언어장애 아동에게 기존에 알고 있는 어휘와 음운적으로 유사한 낱말을 사용하여 빠른 연결하기 를 실시했을 때 음운적 유사성이 아동의 빠른 연결하기 수행 전략 에 미치는 영향을 알아본 결과, 기존의 어휘와 목표 어휘의 음운적 유사성이 높을수록 단순언어장애 아동의 상호배제 전략 적용에 결함을 보였고, 아동의 아동의 수용어휘 점수와 빠른 연결하기 수 행력이 정적 상관이 있다는 것을 밝혔다. Lee와 Choi (2011)는 만 2-5세의 일반 아동 및 정신지체 아동을 대상으로 의미 단서에 따른 빠른 연결 능력을 알아본 결과, 각 집단의 의미 단서에 따른 빠른 연 결 능력은 통계적으로 유의한 차이를 보였고 특히 두 집단은 단서 가 없을 때나 기능 의미 단서를 주었을 때보다 형태 의미 단서를 주 었을 때 과제 수행 능력이 더 높았다는 것을 밝혔다. Han과 Jeong (2000)은 만 3세의 단순언어장애 아동과 정상 아동 집단 간 품사 (명사, 동사)와음운체계(음운체계 내, 음운체계 외)에 따라 빠른 연 결에 차이가 있는지 비교하였을 때, 단순언어장애 아동은 동사 이 해 능력이 정상 아동에 비해 유의하게 낮았고, 단어 산출 면에서는 음운체계 외 단어가 정상 아동보다 단순언어장애 아동 집단에서 유의하게 낮았다. 음운체계가 빠른 연결에 미치는 영향을 보았을 때 단어 이해에서 두 집단 간 유의한 차이는 없었지만, 단어 산출에 서 단순언어장애 아동은 음운체계 외의 단어가 음운체계 내 단어 보다 유의하게 낮은 수행력을 보였다. 또한, 품사 조건에서는 두 집 단 모두 명사조건에서 동사보다 유의하게 높은 수행력을 보였다.

어휘습득을 가능하게 하는 인지적 과정에 대한 가설로 Baddely (1986)는 작업기억(working memory) 모델을 제시하였는데, 이 모 델에 따르면, ‘음운루프(phonological loop)'는 아동이 새롭게 들어 익숙하지 않은 소리들을 의미적인 요소와 연결하여 장기기억에 저 장하기 전에 그 소리(음소)들을 일시적으로 저장해 놓는 곳으로 보 며, 어휘습득 측면에서 음운루프는 새로운 어휘를 습득하는 데 매 우 중요한 역할을 한다고 설명하고 있다(Baddeley, Gathercole, \& Papagno, 1998). 이와 관련하여 어휘 학습을 설명하는 기제로 '음 운단기기억(phonological short-term memory)' 능력에 주목하기 도 하는데, 아동이 새로운 어휘를 받아들일 때에는 기존에 저장된 음운적, 의미적, 구문적, 그리고 비언어적 정보들로부터 새로운 어 휘를 적절하게 분리해 낼 수 있어야 하며, 새롭게 저장된 어휘는 음 운적 형태를 지속적으로 꺼내 사용할 수 있도록 충분히 표상으로 저장되어야 한다는 점에서 어휘 습득에 있어서 음운단기기억의 역 할은 중요하다(Gray, 2006).

음운단기기억이란 구어 자극의 심적인 표상을 생성하고 유지하 
는 능력으로(Baddeley et al., 1998; Gathercole, 2006; Gathercole, Hitch, \& Martin, 1997), 청각적으로 입력된 구어 자극을 즉각적으 로 재생해 낼 수 있게 한다. 음운단기기억 능력을 측정하기 위한 과 제로는 '비단어 따라 말하기(non-word repetition)'와 '숫자 외우기 (digit span)' 과제를 대표적인 예로 들 수 있다. 비단어 따라 말하기 과제는 친숙하지 않은 소리 패턴을 즉각적으로 반복하기 때문에 오 직 음운루프에 의해 조정되므로, 친숙한 어휘에 대한 자동기억 과 제인 숫자 외우기 과제보다 정교하게 음운단기기억 능력만을 측정 할 수 있다는 장점을 가진다(Gathercole et al., 1997). 음운단기기억 은 비단어 따라말하기에 주요한 역할을 하는데(Gathercole, 2006), 음운루프에 음운적 정보를 일시적으로 저장하는 능력이 제한된 경우 비단어 따라말하기에 어려움을 나타낼 수 있다. 4-6세 아동을 대상으로 한 선행연구(Gathercole, Willis, Baddeley, \& Emslie, 1994) 에서는 비단어 따라 말하기가 청각적 숫자 기억하기(auditory digit span)를 비롯한 다른 음운단기기억 과제에 비하여 아동의 어휘 및 읽기, 이해 등 언어 능력과 높은 상관관계가 있음을 밝힌 바 있으며, 결국 비단어 따라말하기에서의 저조한 수행력은 언어발달 지체 아 동의 어휘습득을 제한하는 음운단기기억의 손상으로 설명할 수 있다(Dispaldro, Leonard, \& Deevy, 2013).

비단어 따라 말하기는 어휘 학습 기저의 음운단기기억 능력을 평가하는 과제로서 많은 연구들에서 사용되어 왔으며(Archibald \& Gathercole, 2006; Gathercole, 2006; Munson, Kurtz, \& Windsor, 2005), 일반 아동과 단순언어장애 아동의 비단어 따라 말하기 수행력을 비교함으로써 비단어 따라 말하기 과제가 임상적으로 유 의미한 선별 도구로 사용될 수 있을지를 검토한 연구들도 꾸준히 있어 왔다. 영어(Chiat \& Roy, 2007), 이탈리아어(Bortolini et al., 2006; Dispaldro et al., 2013), 스페인어(Girbau \& Schwartz, 2007), 스웨덴 어(Sahlen, Reuterskiold-Wagner, Nettelbladt, \& Radeborg, 1999) 를 사용하는 아동들을 대상으로 한 연구에서는 비단어 따라말하 기의 임상적 선별 도구로서의 타당성이 검증된 반면, 광둥어(Stokes, Wong, Fletcher, \& Leonard, 2006)의 경우 두 집단 간 비단어 따라 말하기의 수행력에 유의한 차이가 나타나지 않는 등 선행 연구들의 결과가 일관되지 않으며, 또한 말 늦은 아동(late talker)과 일반 아 동의 비단어 따라 말하기 수행력을 비교한 국내 연구(Oh \& Yim, 2013)에 의하면 두 집단 간 비단어 따라 말하기에 있어서 유의한수 행력 차이가 나타나지 않았다. 음운단기기억과 관련해 Hwang (2012) 의 연구에서 이중언어환경에서 언어학습을 시작한 22 개월의 매우 어린 아동에게서도 음운단기기억이 어휘학습에 중요한 요인이 되 는지 연구하였다. 음운단기기억을 측정하기 위해 한국어 같은 비단 어와 영어 같은 비단어를 이용하여 한국어-영어 이중언어 아동 16
명과 영어 단일언어 아동 16 명에게 실시하였다. 그 결과, 비단어 따 라말하기 과제와 영어 표현어휘 측정 시 한국어-영어 이중언어 아 동이 영어 단일언어 아동에 비해 유의미하게 낮은 수행력을 보였다. 그러나 한국어-영어 이중언어 아동의 한국어 표현어휘 수와 영어 표현어휘 수를 합한 총 표현어휘 수는 영어 단일언어 아동의 표현어 휘 수와비교했을 때 통계적으로 유의미한 차이를 보이지 않았다.

본 연구에서는 만 2 세에서 6 세 아동을 대상으로 하여 연령을 광 범위하게 잡았으므로 연령별 수행 차이가 나타날 수 있기에 이에 대한 분석도 실시하였다. 또한, 어휘발달지체 아동과 일반 아동을 대상으로 비단어 따라말하기 과제 및 빠른 우연학습 과제 수행력 을 비교하여 임상적 선별 도구로서의 타당성을 검토해 보고자 하 며, 비단어 따라말하기 과제와 빠른 우연학습 과제가 아동의 어휘 력을 예측하는 도구가 될 수 있는지를 알아보고자 한다.

\section{연구 방법}

\section{연구 대상}

본 연구는 경기도 지역에 거주하는 만 2-6세의 어휘발달지체 아 동 19 명(남아 11 명, 여아 8 명)과 생활연령 및 성별이 일치하는 일반 아동 19 명, 총 38 명을 대상으로 하였다.

어휘발달지체아동은 수용·표현 어휘력검사(receptive and expressive vocabulary test, REVT; Kim, Hong, Kim, Jang, \& Lee, 2009) 결과 1) 수용 및 표현 어휘력 점수가 모두 - $1.5 \mathrm{SD}$ 보다 낮아 어휘연 령이 생활연령보다 1-3년 떨어지면서, 2) 기타 행동, 정서, 시각 및 청 각 등의 감각장애와 기질적인 문제가 없는 아동을 대상으로 하였 다. 정상아동은 수용·표현 어휘력검사(REVT; Kim et al., 2009) 결 과, 1) 수용 및 표현 어휘력 점수가 모두 정상 범주(-1 SD 이상)에 속 하며, 2) 기타 행동, 정서, 시각 및 청각 등의 감각장애와 기질적인 문 제가 없는 아동을 대상으로 하였다.

본 연구에 선정된 어휘발달지체 아동의 평균 생활연령은 만 4 세 4 개월( $\mathrm{SD}=16.8)$, 수용어휘력 평균점수는 24.11점( $\mathrm{SD}=17.0)$, 표현 어휘력 평균점수는 $28.95(\mathrm{SD}=22.2)$ 였다. 그리고 일반아동 집단의 평균 생활연령은 만 4 세 5 개월 $(\mathrm{SD}=16.5)$, 수용어휘력 평균점수는 49.26점 $(\mathrm{SD}=23.3)$, 표현어휘력 평균점수는 $54.89(\mathrm{SD}=22.4$ )였다. 생활연령과 표현어휘력 점수에 대한 집단 간 차이는 유의하지 않았 으나, 수용어휘력 점수에 대한 집단간차이는 유의하였다 $(t=-3.809$, $p<.05)$. 즉, 어휘발달지체 아동의 수용어휘력 점수가 일반 아동의 수용어휘력 점수에 비해 유의하게 낮았다. 실험에 참여한 아동들 의 생활연령, 수용 표현 어휘력 검사점수의 결과는 Table 1 에 제시 하였다. 
는 Appendix 1에 제시하였다.

Table 1. Participants' characteristics

\begin{tabular}{lcc}
\hline \multirow{2}{*}{ Characteristic } & \multicolumn{2}{c}{ Vocabulary score } \\
\cline { 2 - 3 } & $\mathrm{VD}(\mathrm{N}=19)$ & $\mathrm{NL}(\mathrm{N}=19)$ \\
\hline Age $(\mathrm{mo})$ & $52.79(16.80)$ & $53.74(16.46)$ \\
Receptive vocabulary $^{*}+$ & $24.11(16.97)$ & $49.26(23.26)$ \\
Expressive vocabulary $^{\dagger}$ & $28.95(22.23)$ & $54.89(22.41)$ \\
\hline
\end{tabular}

Values are presented as mean (SD).

$\mathrm{VD}=$ children with delay in vocabulary development; $\mathrm{NL}=$ children with normal language.

${ }^{*} p<.05,{ }^{\dagger}$ Receptive \& expressive vocabulary test (Kim, Hong, Kim, Jang, \& Lee, 2009).

\section{연구 도구}

선별검사의 실시 절차 및 방법

수용·표현 어휘력 검사

실험집단인 어휘발달지체 아동집단과 통제집단인 일반 아동 집 단의 어휘력을 살펴보기 위해 수용·표현 어휘력검사(REVT; Kim et al., 2009)를 실시하였다. 이 검사는 만 2세 6개월부터 16세까지 아동 및 청소년의 수용 및 표현 어휘능력을 측정하기 위하여 제작 된 검사 도구로서, 그림을 보여주고 해당하는 그림의 이름이나 동 작을 말하고, 4 개의 그림 목록에서 검사자가 말한 해당 어휘를 고 르는 방식으로 진행되었다. 본 연구에서는 수용·표현 어휘력검사 의 결과가 어휘발달지체 아동 집단과 일반 아동 집단의 선별 도구 로서 사용되었으며, 수용 및 표현 어휘력이 모두 $-1.5 \mathrm{SD}$ 미만인 경 우 어휘발달지체 아동으로, 수용 및 표현 어휘력이 모두 - $1 \mathrm{SD}$ 이상 인 경우 일반 아동 집단으로 구분되었다.

\section{본 검사의 실시 절차 및 방법}

비단어 따라 말하기(NWR) 과제

비단어 따라 말하기 과제는 Lee 등(2012)의 과제를 사용하였다. 이 과제는 음절길이 $(2,3,4,5,6$ 음절 $)$ 에 따른 아동의 음운단기기억 수행력을 측정할 수 있으며 각 음절길이마다 4 개씩, 총 20 개의 단어 로 구성되어 있다. Lee 등(2012)의 비단어따라말하기 과제는, Lee (2010)의 비단어 따라말하기 단어목록에서 단어유사성이 낮은 20 개의 단어들을 음소 배열론적 확률(phonotactic probability)이 낮은 음절의 음소를 높은 음절의 음소로 수정하여 친숙한 음소적 균형 으로 맞출수 있도록 음소를 수정 및 첨가하였다(Oh \& Yim, 2013). 검사자는 아동에게 녹음된 비단어 음성파일을 컴퓨터로 들려주며 앵무새처럼 똑같이 따라 말하도록 지시하고, 아동은 검사자의 지 시에 맞게 따라 말하기 과제를 수행하였다. 채점기준은 바르게 따 라 말한 음절에 1점을 부여하여 각 문항별로 정 조음한 음절 수를 기록하고, 처음 문항부터 마지막 문항까지의 점수를 종합해 총점 을 기록하였다. 본 연구에 사용된 비단어 따라 말하기(NWR) 과제
빠른 우연학습(QUIL) 과제

빠른 우연학습 과제는 빠른 연결 능력을 알아보기 위한 과제로 약 5 분 분량의 2 개의 애니메이션 영상 안에 목표 어휘가 삽입되어 아동에게 제시되었다. 애니메이션 영상은 캐릭터 및 이야기 구조가 익숙하지 않은 독일어권의 애니메이션인 "Der MaulwurfalsFotograf"와 "Der Maulwurf und der Fernseher"영상을 가져와 한국어 목소리를 입혔다. 애니메이션에 삽입된 구문표현은 학령 전 아동이 이해하기 쉽도록 구성하였다.

연구자는 먼저 조용한 방 안에서 검사자와 아동이 일대일로 앉 을 수 있도록 준비한 후 노트북과 헤드폰을 준비하고, 아동이 비디 오를 시청하기 전 헤드폰을 착용할 수 있도록 한다. 연구자는 비디 오를 보여주기 전, 아동에게 비디오를 본 다음 질문을 할 것이니 주 의 깊게 비디오를 시청할 것을 지시한다(예: ‘비디오를 보고 질문을 할 거니까 잘 들어보세요'). 비디오 시청 전, 카메라가 등장하는 화 면을 보여주면서 “토토예요. 쥐가 카메라를 닦아요”라는 내용이 나오는 부분을 보여준 후, 아동의 헤드폰에서 소리가 잘 들리는지 확인한 후 비디오를 시청하도록 한다. 연구에 사용된 2 개의 비디오 는 균형배치(counterbalance)되어 각 아동에게 제시된다. 아동이 비디오 영상을 시청하는 중 아동이 화면을 보지 않는 경우에는, 화 면을 가리키며 “여기를 보세요”라고 말하며 즉각 화면을 보도록 주의를 환기시켰다. 각 비디오 시청이 끝나면 즉시 영상 속에서 제 시된 목표단어(가상단어)가 습득되었는지 확인하기 위해 수용어 휘(이해) 검사를 실시하였다. 검사 실시 방법으로는 비디오 시청이 끝나면 아동에게 4 개의 그림이 그려진 그림판을 제시하고, 검사자 가 들려 주는 목표 단어를 듣고 아동이 4가지 그림 중 정답을 손으 로 가리키는 방식으로 진행되었다. 예를 들어, 검사자가 "여기 4개 그림 중에서 아까 봤던 ‘두비’가 어디 있지?”라고 물으면 아동은 ‘두 비’라고 생각되는 그림을 가리키는 방식이다. 두 번째 제시되는 비 디오 역시 시청이 끝나면 같은 방식으로 검사가 실시되었다.

과제에 포함된 목표단어는 명사와 동사 각각 5 개로 총 10 개의 새 로운 단어가 애니메이션 자료에 삽입되었으며, 채점기준은 10 개의 목표어휘 중 아동이 정반응한 문항에 1점을 부여하고, 총 10 개의 문항 중 정반응한 문항의 수를 점수로 기록하였다. 본 연구에 사용 된 빠른 우연학습(QUIL) 과제의 결과 기록지는 Appendix 2, 비디 오 내용 스크립트는 Appendix 3, 빠른 우연학습 검사 그림자료의 예시는 Appendix 4에 제시하였다. 


\section{자료분석 및 결과처리}

본 연구에서는 SPSS ver. 19 (SPSS Inc., Chicago, IL, USA)를 사 용하여 통계적 처리를 실시하였다. 연령에 따른 집단 간 비단어 따 라 말하기 수행 능력, 빠른 우연학습 능력의 차이가 있는지 비교하 기 위해 이원분산분석(two-way ANOVA)을 실시하였고, 그 결과 연령에 따른 수행 차이를 보였던 NWR(비단어따라말하기)의 경우 에는 연령을 통제하여 공변량분석(ANCOVA)을 추가적으로 실시 하였다. 두 집단에서 각 변인들과 REVT수용어휘 간의 상관관계를 살펴보기 위해 Pearson 상관분석을 실시하였으며, 각 집단의 어휘 학습(REVT 수용어휘)을 예측할 수 있는 변인을 알아보기 위해 단 계적 중다회귀분석(stepwise multiple regression)을 실시하였다.

\section{연구 결과}

\section{각 연령에 따른 집단 간 비단어 따라 말하기 능력, 빠른 우연학습 능력 비교}

만 2-6세의 각 연령에 따른 집단 간 비단어 따라 말하기 수행 능 력, 빠른 우연학습 능력의 차이가 있는지 비교하기 위해 이원분산 분석(two-way ANOVA)을 실시하였다.

Table 2. NWR performance (\%) by groups with NL and VD on the NWR task

\begin{tabular}{lll}
\hline \multirow{2}{*}{ Age (yr) } & \multicolumn{2}{c}{ NWR performance $(\%)$} \\
\cline { 2 - 3 } & \multicolumn{1}{c}{ VD (N=19) } & NL (N=19) \\
\hline 2 & $25.00(17.19)$ & $45.67(24.58)$ \\
3 & $25.00(28.63)$ & $56.20(22.72)$ \\
4 & $43.44(8.38)$ & $69.75(21.79)$ \\
5 & $67.50(24.75)$ & $95.50(0.71)$ \\
6 & $62.25(15.77)$ & $78.40(11.46)$ \\
\hline
\end{tabular}

Values are presented as mean (SD).

NWR= non-word repetition; $\mathrm{VD}=$ children with delay in vocabulary development; $\mathrm{NL}=$ children with normal language.

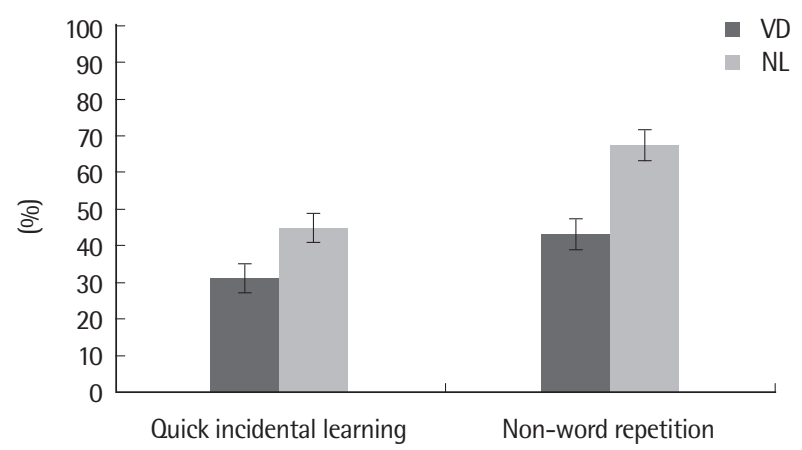

Figure 1. Non-word repetition and quick incidental learning performance (\%) in VD and $\mathrm{NL}$. VD = children with delay in vocabulary development; $\mathrm{NL}=$ children with normal language.
비단어 따라 말하기 수행에서 각 연령에 따른 수행 차이를 비교한 결과, 연령에 따른 차이가 통계적으로 유의하였으며 $\left(F_{(4,28)}=6.140\right.$, $p<.01)$, 이에 따라 Bonferroni 사후비교분석을 실시한 결과, 유의 한 수행 차이가 있었던 연령은 각각 2 세와 5 세, 2 세와 6 세, 3 세와 5 세, 3 세와 6 세였다 $(p<.05)$. 각 집단에 따른 수행 또한 통계적으로 유의하였다 $\left(F_{(1,28)}=12.945, p<.01\right)$. 연령 및 집단 간 상호작용 효과 는 통계적으로 유의미한 차이가 나타나지 않았다 $\left(F_{(4,28)}=0.210\right.$, $p>.05)$. 비단어 따라 말하기 과제의 경우, 연령에 따른 수행 차이를 보였기에 연령을 통제하여 공변량분석(ANCOVA)를 실시한 결과, 비단어 따라 말하기 수행에서 어휘발달 지체 아동 집단 $(\mathrm{M}=43.16$, $\mathrm{SD}=25.09)$ 은 일반아동 집단 $(\mathrm{M}=67.37, \mathrm{SD}=22.94)$ 에 비해 낮았 다 $(p<.001)$.

빠른 우연학습 수행에서는 각 연령에 따른 수행 차이가 통계적으 로 유의하지 않았으며 $\left(F_{(4,28)}=2.372, p>.05\right)$, 각 집단에 따른 수행 은 통계적으로 유의하였다 $\left(F_{(1,28)}=5.931, p<.05\right)$. 즉, 언어발달 지 체 아동 집단 $(\mathrm{M}=31.05, \mathrm{SD}=17.29)$ 이 일반 아동 집단 $(\mathrm{M}=44.74$, $\mathrm{SD}=18.37)$ 에 비해 빠른 우연학습 수행력이 통계적으로 유의하게 낮았다 $(p<.05)$. 빠른 우연학습의 연령 및 집단 간 상호작용 효과는 통계적으로 유의미한 차이가 나타나지 않았다 $\left(F_{(4,28)}=.125, p>.05\right)$. 위와 같은 결과에 대한 그래프는 Table 2, Figure 1과 같다.

\section{두 집단에서 각 변인들과 REVT 수용어휘 간의 상관관계}

어휘발달지체 아동 집단과 일반 아동 집단에서 각 변인인 수용 어휘력 점수, 음운단기기억능력(NWR), 빠른 우연학습(QUIL) 간 의 상관관계를 알아보기 위하여 Pearson 상관계수를 측정하였다. 그 결과, 어휘발달지체 아동 집단에서 수용어휘는 비단어 따라 말 하기 $(r=0.733, p<.01)$ 만이 유의한 상관관계를 보였고, 일반 아동 집단에서 수용어휘는 비단어 따라 말하기 $(r=0.498, p<.01)$, 빠른 우연학습 $(r=0.556, p<.05)$ 이 모두 유의한 상관관계를 보였으며, 비단어 따라 말하기와 빠른 우연학습 간의 상관관계 $(r=0.456, p<$ .05)도 통계적으로 유의하였다. 자세한 결과는 Tables 3,4 와 같다.

\section{두 집단의 어휘력(REVT 수용어휘)을 예측할 수 있는 변인}

각 집단의 어휘력(REVT 수용어휘)의 예측변수가 무엇인지 살펴

Table 3. The correlation coefficient among various variables and receptive vocabulary in children with delay in vocabulary development group

\begin{tabular}{lcc}
\hline Variable & Receptive vocabulary & Non-word repetition \\
\hline Non-word repetition & $0.733^{*}$ & - \\
Quick incidental learning & 0.424 & 0.237 \\
\hline${ }^{*} p<.01$. & &
\end{tabular}


Table 4. The correlation coefficient among various variables and receptive vocabulary in typically developing children group

\begin{tabular}{lcc}
\hline Variable & Receptive vocabulary & Non-word repetition \\
\hline Non-word repetition & $0.498^{* *}$ & - \\
Quick incidental learning & $0.556^{*}$ & $0.456^{*}$ \\
\hline
\end{tabular}

${ }^{*} p<.05,{ }^{* *} p<.01$.

보기 위하여 단계적 중다회귀분석(stepwise multiple regression)을 실시하였다. 어휘발달지체 아동 집단의 경우, 2 가지 독립변수(비단 어 따라 말하기, 빠른 우연학습) 중 수용어휘를 유의하게 예측한 변 수는 비단어 따라 말하기 $\left(F_{(1,17)}=19.766, p<.001, \mathrm{R}^{2}=.538\right)$ 로 나타 났으며, 일반 아동 집단의 수용어휘를 유의하게 예측한 변수는 빠 른 우연학습 $\left(F_{(1,17)}=7.609, p<.05, \mathrm{R}^{2}=.309\right)$ 인 것으로 나타났다.

\section{논의 및 결론}

본 연구에서는 학령 전 일반 아동과 어휘발달지체 아동의 음운 단기기억능력, 어휘능력, 그리고 빠른 우연학습능력 간의 관계를 살펴보았다. 일반 아동 집단과 어휘발달지체 아동 집단 간의 빠른 우연학습 및 비단어 따라 말하기 과제에서의 수행력의 차이가 있 는지 알아보기 위해 이원분산분석(two-way ANOVA) 및 공변량분 석(ANCOVA)을 실시한 결과, 빠른 우연학습 과제를 통해 새 단어 를 학습(수용어휘)하는 능력과 비단어 따라 말하기를 통한 음운단 기기억 능력 모두 어휘발달지체 아동이 일반아동보다 유의하게 낮 은 것으로 나타났다. 이는 어휘발달지체 아동이 어휘를 학습할 때 일반아동에 비해 빠른 우연학습 능력 및 암묵적 학습 능력, 음운단 기기억 능력을 충분히 활용하지 못하여 어휘학습에 들이는 노력이 일반 아동에 비해 더 필요할 수 있음을 나타내는 결과이다.

또한, 이는 말 늦은 아동(late talker)과 일반 아동 집단 간 비단어 따라말하기 과제에서 유의한 차이가 나타나지 않은 선행연구(Oh \& Yim, 2013)와 상반되는 결과이다. 동일한 과제를 사용했음에도 상반된 연구결과가 나온 이유는, 연구 대상이 2-3세의 말 늦은 아 동(수용어휘력 - $1.25 \mathrm{SD}$ 미만)과 2-6세의 어휘발달지체 아동(수용 및 표현어휘력 $-1.5 \mathrm{SD}$ 미만)으로 달랐다는 점에 주목할 수 있다. 본 연구에서도 분산분석 결과 비단어 따라 말하기 수행에 대한 연령 의 주효과가 유의한 것으로 나타났고 특히 만 2세와 5세, 2 세와 6 세, 3 세와 5 세, 3 세와 6 세에서 수행의 차이가 유의하였기에 대상 아 동의 연령이 달랐던 두 연구의 결과는 아동의 연령에 영향을 받았 을 것임을 추론해 볼 수 있다.

각 과제 간의 상관관계를 분석한 결과, 어휘발달지체 아동 집단 에서는 수용어휘와 비단어 따라 말하기가 유의한 상관관계를 보였
고, 일반 아동 집단에서는 수용어휘와 비단어 따라 말하기, 그리고 수용어휘와 빠른 우연학습 간 유의한 상관관계가 나타났다. 일반 아동 집단에서 나타난 수용어휘와 빠른 우연학습 간의 유의한 상 관관계가 어휘발달지체 아동 집단에서 나타나지 않은 것은, 빠른 우연학습 과제의 기저 능력인 암묵적인 어휘 학습 능력을 어휘발달 지체 아동들은 충분히 활용하지 않는다는 의미로 해석할 수 있다. 즉, 어휘발달지체 아동들은 새로운 어휘를 학습할 때 암묵적으로 학습하기보다는 음운단기기억과 같은 단기적 기억 능력에 의존하 고 있음을 본 연구의 결과로 추론해 볼수 있다.

단계적 회귀분석으로 각 집단의 수용어휘능력을 가장 잘 예측 해줄 수 있는 변인이 무엇인지 알아본 결과, 일반 아동 집단에서는 빠른 우연학습이 수용어휘 능력을 가장 잘 예측해 줄 수 있는 변인 으로 나타난 반면, 어휘발달지체 아동 집단에서는 빠른 우연학습 이 아닌 비단어 따라 말하기가 수용어휘 능력을 가장 잘 예측해 줄 수 있는 것으로 나타났다. 이는 일반 아동의 경우 새로운 어휘를 참 조물과 빠르게 연결시켜 암묵적으로 학습하는 능력을 어휘 학습 에서 충분히 활용하는 반면 어휘발달지체 아동의 경우 음운단기기 억과 같은 단기적 기억능력을 어휘학습에서 주로 사용하고 있음을 의미한다. 즉, 일반 아동이 효율적인 암묵적 학습 방식으로 어휘를 습득한다면, 수용어휘발달 지체 아동은 단기적 기억 용량에 의존 하는 학습 방식을 사용함으로써 어휘학습에 있어서 일반 아동에 비해 비효율성을 초래한다고 할 수 있다. 따라서 어휘발달지체 아 동에게 암묵적 학습을 증진시킬 수 있는 중재를 제공하는 것이 임 상적으로 유의미한 결과를 가져올 것으로 예측되며, 이에 대한 후 속 연구가 필요할 것으로 보인다.

단순언어장애 아동을 대상으로 한 선행연구(Alt \& Plante, 2006; Nash \& Donaldson, 2005)에 의하면 어휘력이 부족한 아동이 어휘 습득에서 보이는 어려움은 명시적 학습(explicit learning context) 에서보다 암묵적인 이야기 문맥(story context)에서 더 두드러지게 나타났다. 본 연구에서 사용된 비단어 따라말하기는 제시된 비단 어를 즉각적으로 모방하여 산출해 내는 명시적 학습에 해당하며, 빠른 우연학습은 영상을 보면서 이야기 문맥 안에서 새로운 어휘 를 암묵적으로 학습하는 과제이다. 따라서 단순언어장애 아동과 마찬가지로 어휘발달지체 아동 또한 명시적 학습 과제에서보다 이 야기 문맥 과제에서의 어휘 학습에 더욱 어려움을 보였을 가능성 이 있으므로, 두 집단의 어휘능력 예측 변인이 각각 다르게 나타났 음을 추론해 볼수 있다.

한편 Baddeley의 작업기억(working memory) 모델에서 음운루 프(phonological loop)는 입력된 새로운 음운목록(novel phonological sequence)을 작업기억에 단기적으로 저장하여 장기기억이 될 
때까지 유지하는 역할을 하는데(Baddeley, 2003), 이를 고려해 볼 때 기억저장 훈련을 지속적으로 하는 것이 어휘발달지체 아동의 어휘습득 능력 향상에 도움을 줄 수 있을 것으로 기대되며(Hulme \& Snowling, 2009), 비단어 따라 말하기가 어휘발달지체 아동의 어 휘력을 유의하게 예측하는 변수로서 나타난 본 연구의 결과도 이 를 지지한다고 하겠다.

본 연구는 대상 아동 집단에 대하여 수용-표현 어휘력 검사 외의 다른 지능검사 및 전반적 언어발달 검사를 시행하지 않은 바, 집단 을 수용어휘력을 기준으로 구분하여 수용어휘발달지체 아동 집단 으로 대상 집단의 범위가 좁아진 한계가 있다. 이에 후속 연구에서 는 복수의 언어발달검사 및 지능검사를 실시하여 대상집단을 더욱 명확하게 분류하여 연구결과를 강화하고 일반화하는 데에 기여할 수 있기를 제언한다.

후속 연구에서는 언어발달 지체 아동을 대상으로 기억저장 훈련 이 어휘습득 능력에 미치는 영향을 검토해 볼 것을 제안하며, 새로 운 단어 혹은 비단어를 처리할 때는 어휘적, 음운적 정보 모두에 의 존할 수 있고(Storkel \& Morrisette, 2002), 의미자질의 빠른 연결이 비단어 따라 말하기와도 유의한 상관관계가 있다는 선행연구(Alt \& Plante, 2006)에 근거하여, 더 큰 표본 집단을 대상으로 하여 빠 른 연결학습 및 비단어 따라 말하기뿐 아니라 의미자질이 개입된 실제 단어 따라 말하기(real-word repetition) 혹은 문장 따라 말하 기(sentence repetition) 능력 등 어휘능력을 예측해 줄 수 있는 가 능성을 지닌 보다 다양한 변인들을 통해 어휘 학습 기제를 밝히는 후속연구가 또한 필요할 것으로 보인다.

\section{REFERENCES}

Alt, M., \& Plante, E. (2006). Factors that influence lexical and semantic fast mapping of young children with specific language impairment. Journal of Speech, Language and Hearing Research, 49, 941-954.

Alt, M., Plante, E., \& Creusere, M. (2004). Semantic features in fast-mapping: performance of preschoolers with specific language impairment versus preschoolers with normal language. Journal of Speech, Language and Hearing Research, 47, 407-420.

Archibald, L. M. D., \& Gathercole, S. E. (2006). Nonword repetition: a comparison of tests. Journal of Speech, Language, and Hearing Research, 49, 970983.

Baddeley, A. (2003). Working memory and language: an overview. Journal of Communication Disorders, 36, 189-208.

Baddeley, A. D. (1986). Working memory. Oxford: Oxford University Press.
Baddeley, A., Gathercole, S., \& Papagno, C. (1998). The phonological loop as a language learning device. Psychological Review, 105, 158-173.

Bishop, D. V. (1992). The underlying nature of specific language impairment. Journal of Child Psychology and Psychiatry, 33, 3-66.

Bortolini, U., Arfe, B., Caselli, C. M., Degasperi, L., Deevy, P., \& Leonard, L. B. (2006). Clinical markers for specific language impairment in Italian: the contribution of clitics and non-word repetition. International Journal of Language \& Communication Disorders, 41, 695-712.

Carey, S., \& Bartlett, E. (1978). Acquiring a single new word. Child Language Development, 15, 17-29.

Chiat, S., \& Roy, P. (2007). The preschool repetition test: an evaluation of performance in typically developing and clinically referred children. Journal of Speech, Language and Hearing Research, 50, 429-443.

Dispaldro, M., Leonard, L. B., \& Deevy, P. (2013). Real-word and nonword repetition in Italian-speaking children with specific language impairment: a study of diagnostic accuracy. Journal of Speech, Language and Hearing Research, 56, 323-336.

Dollaghan, C. (1985). Child meets word: "fast mapping" in preschool children. Journal of Speech, Language and Hearing Research, 28, 449-454.

Gathercole, S. E. (2006). Nonword repetition and word learning: the nature of the relationship. Applied Psycholinguistics, 27, 513-543.

Gathercole, S. E., \& Baddeley, A. D. (1990). Phonological memory deficits in language disordered children: is there a causal connection? Journal of Memory and Language, 29, 336-360.

Gathercole, S. E., Hitch, G. J., \& Martin, A. J. (1997). Phonological short-term memory and new word learning in children. Developmental Psychology, $33,966-979$.

Gathercole, S. E., Willis, C. S., Baddeley, A. D., \& Emslie, H. (1994). The children's test of nonword repetition: a test of phonological working memory. Memory, 2, 103-127.

Girbau, D., \& Schwartz, R. G. (2007). Non-word repetition in Spanish-speaking children with specific language impairment (SLI). International Journal of Language \& Communication Disorders, 42, 59-75.

Golinkoff, R. M., Hirsh-Pasek, K., Bailey, L. M., \& Wenger, N. R. (1992). Young children and adults use lexical principles to learn new nouns. Developmental Psychology, 28, 99-108.

Gray, S. (2006). The relationship between phonological memory, receptive vocabulary, and fast mapping in young children with specific language impairment. Journal of Speech, Language and Hearing Research, 49, 955969. 
Yoonhee Yang, et al. • The Relationship among Receptive Vocabulary, NWR, and QUIL

Han, J. Y., \& Jeong, O. R. (2000). A comparative study on the fast mapping between children with specific language impairment and normal language. Journal of Speech \& Hearing Disorders, 9, 23-39

Howell, S. R., Jankowicz, D., \& Becker, S. (2005). A model of grounded language acquisition: sensorimotor features improve lexical and grammatical learning. Journal of Memory and Language, 53, 258-276.

Hulme, C., \& Snowling, M. J. (2009). Disorders of language, learning and cognition. Chichester: Wiley-Blackwell.

Hwang, B. M. (2012). Vocabulary development and phonological short-term memory in Korean-English bilingual children and English monolingual children. Bilingual Research, 20, 329-352.

Kail, R., Hale, C. A., Leonard, L. B., \& Nippold, M. A. (1984). Lexical storage and retrieval in language-impaired children. Applied Psycholinguistics, 5, $37-49$.

Kim, S. S. (2005). The role of phonological similarity of target words on fastmapping strategy of children with SLI. Korean Journal of Communication Disorders, 10, 25-42.

Kim, Y. T., Hong, G. H., Kim, K. H., Jang, H. S., \& Lee, J. Y. (2009). Receptive \& expressive vocabulary test (REVT). Seoul: Seoul Community Rehabilitation Center.

Lee, H. J. (2010). The influences of number of syllables and wordlikeness on 3-to 5-year-old Korean-English bilingual children's nonword repetition (Master's thesis). Ewha Womans University, Seoul, Korea.

Lee, H. M., \& Choi, Y. L. (2011). Comparison of fast-mapping according to semantic cues of normal children and children with mental retardation. Journal of Speech-Language \& Hearing Disorders, 20, 87-102.

Lee, Y., Yim, D., \& Sim, H. (2012). Phonological processing skills and its relevance to receptive vocabulary development in children with early cochlear implantation. International Journal of Pediatric Otorhinolaryngology, 76, 1755-1760.

Leonard, L. B. (1989). Language learnability and specific language impairment in children. Applied Psycholinguistics, 10, 179-202.

Markman, E. M. (1989). Categorization and naming in children: problems of induction. Cambridge, MA: MIT Press.

McBride-Chang, C., Cho, J. R., Liu, H., Wagner, R. K., Shu, H., Zhou, A., ... Muse, A. (2005). Changing models across cultures: associations of phonological awareness and morphological structure awareness with vocabulary and word recognition in second graders from Beijing, Hong Kong, Korea, and the United States. Journal of Experimental Child Psychology, 92, 140-160. McGregor, K. K., Newman, R. M., Reilly, R. M., \& Capone, N. C. (2002). Se- mantic representation and naming in children with specific language impairment. Journal of Speech, Language and Hearing Research, 45, 998-1014. Michas, I. C., \& Henry, L. A. (1994). The link between phonological memory and vocabulary acquisition. British Journal of Developmental Psychology, $12,147-163$.

Munson, B., Kurtz, B. A., \& Windsor, J. (2005). The influence of vocabulary size, phonotactic probability, and wordlikeness on nonword repetitions of children with and without specific language impairment. Journal of Speech, Language and Hearing Research, 48, 1033-1047.

Nash, M., \& Donaldson, M. L. (2005). Word learning in children with vocabulary deficits. Journal of Speech, Language and Hearing Research, 48, 439458.

Oetting, J. B., Rice, M. L., \& Swank, L. K. (1995). Quick incidental learning (QUIL) of words by school-age children with and without SLI. Journal of Speech, Language and Hearing Research, 38, 434-445.

Oh, D. Y., \& Yim, D. (2013) Non-word repetition and sentence repetition performance in 2-3 years old late talkers and normal children. Communication Sciences \& Disorders, 18, 277-287.

Penno, J. F., Wilkinson, I. A., \& Moore, D. W. (2002). Vocabulary acquisition from teacher explanation and repeated listening to stories: do they overcome the Matthew effect? Journal of Educational Psychology, 94, 23-33.

Rice, M. L., Buhr, J. C., \& Nemeth, M. (1990). Fast mapping word-learning abilities of language-delayed preschoolers. Journal of Speech and Hearing Disorders, 55, 33-42.

Sahlen, B., Reuterskiold-Wagner, C., Nettelbladt, U., \& Radeborg, K. (1999). Non-word repetition in children with language impairment-pitfalls and possibilities. International Journal of Language \& Communication Disorders, 34, 337-352.

Snowling, M. J., \& Hulme, C. (2007). Developmental cognitive disorders. Oxford: Blackwell.

Stokes, S. F., Wong, A. M., Fletcher, P., \& Leonard, L. B. (2006). Nonword repetition and sentence repetition as clinical markers of specific language impairment: the case of Cantonese. Journal of Speech, Language and Hearing Research, 49, 219-236.

Storkel, H. L. (2001). Learning new words: phonotactic probability in language development. Journal of Speech, Language, and Hearing Research, 44, 1321-1337.

Storkel, H. L., \& Morrisette, M. L. (2002). The lexicon and phonology: interactions in language acquisition. Language, Speech, and Hearing Services in Schools, 33, 24-37. 
Appendix 1. Non-word repetition

비단어 따라 말하기 결과 기록지

\begin{tabular}{|l|l|l|l|l|}
\hline 아동 이름(성별) & 생년월일(생활연령) & & \\
\hline 장애 유무 & 검사일(검사자) & & \\
\hline
\end{tabular}

\begin{tabular}{|c|c|c|c|c|}
\hline 문항 & 비단어 & 아동반응 & 점수 & 비고 \\
\hline 1 & 누베 & & & \\
\hline 2 & 마뚜 & & & \\
\hline 3 & 조나 & & & \\
\hline 4 & 퍼틱 & & & \\
\hline 5 & 버줍디 & & & \\
\hline 6 & 까다굳 & & & \\
\hline 7 & 모단기 & & & \\
\hline 8 & 니아토 & & & \\
\hline 9 & 토보가인 & & & \\
\hline 10 & 머구낭뿔 & & & \\
\hline 11 & 푸가태지 & & & \\
\hline 12 & 드반거노 & & & \\
\hline 13 & 조매누버리 & & & \\
\hline 14 & 레빌애티머 & & & \\
\hline 15 & 누빈재구밈 & & & \\
\hline 16 & 바즘다거니 & & & \\
\hline 17 & 무지다바리노 & & & \\
\hline 18 & 로밉띠르저니 & & & \\
\hline 19 & 보마데낭까두 & & & \\
\hline 20 & 미기돋아캐바 & & & \\
\hline 총점 & & & & \\
\hline
\end{tabular}


Yoonhee Yang, et al. • The Relationship among Receptive Vocabulary, NWR, and QUIL

Appendix 2. Quick incidental learning (QUIL) scoring sheet

빠른 우연학습 결과 기록지

\begin{tabular}{|l|l|l|l|l|l|}
\hline 아동명 & 생년월일 & & 성별/그룹 & \\
\hline
\end{tabular}

\begin{tabular}{|c|c|c|c|c|c|c|}
\hline \multicolumn{7}{|c|}{ QUIL } \\
\hline \multirow{2}{*}{ 번호 } & \multirow{2}{*}{ 비디오 } & \multirow{2}{*}{\multicolumn{2}{|c|}{ 자극어 }} & \multicolumn{3}{|r|}{ 수용어휘 } \\
\hline & & & & 정답 & 아동반응 & 결과 \\
\hline 1 & \multirow{4}{*}{ 카메라 이야기 } & 나구다 & 동사 & 3 & (1) (2) (3) (4) & \\
\hline 2 & & 두비 & 명사 & 2 & (1) (2) (3) (4) & \\
\hline 3 & & 태파다 & 동사 & 4 & (1) (2) (3) (4) & \\
\hline 4 & & 가배다 & 동사 & 1 & (1) (2) (3) (4) & \\
\hline 5 & \multirow{6}{*}{ 텔레비전 이야기 } & 노때 & 명사 & 4 & (1) (2) (3) (4) & \\
\hline 6 & & 비너다 & 동사 & 3 & (1) (2) (3) (4) & \\
\hline 7 & & 메꾸 & 명사 & 1 & (1) (2) (3) (4) & \\
\hline 8 & & 하노 & 명사 & 2 & (1) (2) (3) (4) & \\
\hline 9 & & 뽀매다 & 동사 & 4 & (1) (2) (3) (4) & \\
\hline 10 & & 푸차 & 명사 & 3 & (1) (2) (3) (4) & \\
\hline 계 & & & & & & \\
\hline
\end{tabular}


Appendix 3. Quick incidental learning (QUIL) video script

빠른 우연학습 비디오 스크립트

\section{〈카메라 이야기〉}

\section{토토에요.}

쥐가 카메라를 닦아요

또 닦아요.

쥐가 사진을 보여줘요.

사진 찍자.

쥐가 토토를 $*$ 가배요.

이렇게 가배요.

등을 펴서 가배요.

사진을 찍었어요.

와! 멋있어요.

장난감을 꺼내요.

장난감이랑 *나구고 싶어요.

쥐는 그러기 싫어요.

토토가 고양이를 보여줘요.

고양이랑 나구고 싶어요.

고양이가 움직여요.

와! 재미있어요

쥐가 카메라랑 나궈요.

쥐가 고양이를 타고 가요.

토토는 카메라가 좋아요.

카메라 단추를 눌러요.
접혔다.

또 눌러요.

개구리를 불러요.

토토가 사진을 찍어요

어. *두비가 빠졌어요.

사진이 이상해요.

개구리가 *태파고 있어요.

토토가 사진을 밀어요.

북을 치며 태파요.

두비가 빠져 있어요.

벌이 날아가요.

두비를 끼워요.

개구리 사진을 찍어요.

뒤로 가요. 뒤로.

어.. 카메라가 고장났어요.

북을 치며 태파요.

토토가 개구리를 불러요

토토가 그림을 그려요.

개구리 그림이에요.

고슴도치도 그려요.

토끼랑 부엉이도 그려요.

\section{〈텔레비전 이야기〉}

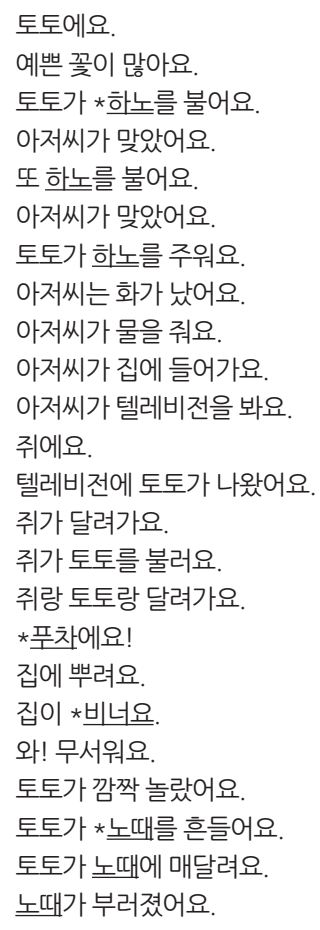

텔레비전이 이상해요.

텔레비전이 안 나와요.

아저씨가 텔레비전을 망가뜨려요.

아저씨가 놀랐어요.

아저씨가 화가 났어요.

아저씨가 토토집을 망가뜨려요

토토가 아저씨를 * 뽀매요.

토토가 아저씨를 뽀매요.

토토가 계속 뽀매요.

아저씨가 화났어요.

화가 많이 났어요.

토토가 쥐를 불러요.

같이 꽃을 심어요.

꽃에 물을 줘요.

아저씨가 푸차를 가져와요

도망가요!

어! *메꾸를 떨어뜨렸어요.

아저씨가 메꼬를 들어요.

메꾸를 집에 꽃아요.

아저씨는 푸차를 버려요.

다 븨너요.

븨너서 없어졌어요.

아저씨는 토토를 불러요.

토토가 나왔어요. 
Yoonhee Yang, et al. • The Relationship among Receptive Vocabulary, NWR, and QUIL

Appendix 4. Multiple choices (picture) of quick incidental learning task

빠른 우연학습 검사 그림자료의 예(“텔레비전 이야기”의 ‘노때’ 고르기)
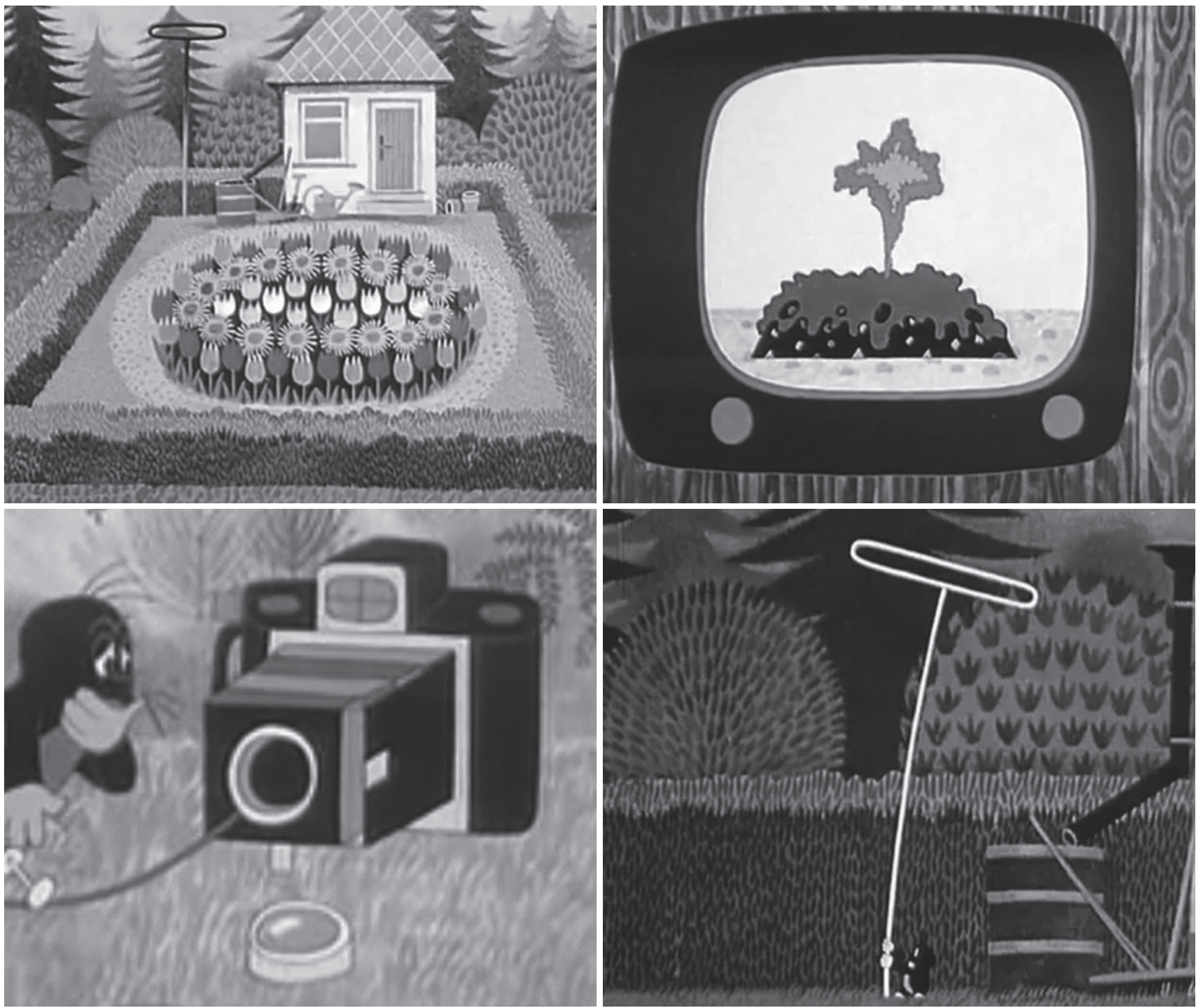


\section{국문초록}

\section{학령 전 어휘발달지체 및 일반 아동의 비단어 따라 말하기, 빠른 우연학습(Quick Incidental Learning)과 수용어휘와의 관계}

양윤희 · 임동선 · 김신영 · 한지윤

이화여자대학교 언어병리학과

배경 및 목적: 본 연구는 학령 전 어휘발달지체 및 일반아동의 비단어 따라 말하기, 빠른 우연학습 능력의 차이점을 분석하고, 각 변인 간 상관관계 및 이미 습득한 수용어휘능력을 가장 잘 예측해 줄 수 있는 변인이 무엇인지 살펴보았다. 방법: 경기 지역에 거주하는 만 2-6세 어휘발달지체 및 일반아동을 대상으로 비단어 따라 말하기 및 빠른 우연학습 과제를 실시하였다. 통계적 처리는 이원분산분석, 공변량분석, 상관 및 회귀분석을 실시하였다. 결과: 빠른 우연학습 과제를 통한 새 단어 학습 능력과 비단어 따라 말하기를 통한 음운 단기기억 능력은 모두 어휘발달지체아동이 일반아동보다 유의하게 낮았다. 어휘발달지체아동 집단에서는 수용어휘와 비단어 따라 말 하기가, 일반아동 집단에서는 수용어휘와 비단어 따라 말하기, 빠른 우연학습이 유의한 상관을 나타냈다. 일반아동 집단에서는 빠른 우연학습이 가장 큰 예측요인으로 나타난 반면, 어휘발달지체아동 집단에서는 비단어 따라 말하기가 가장 잘 예측해 줄 수 있었다. 논 의 및 결론: 학령 전의 어린 연령에서는 어휘학습 시 암묵적 학습능력이 매우 중요하게 나타났으며, 어휘발달지체 아동의 경우 이러한 암묵적 학습능력이 영향력을 발휘하지 못하고 오직 음운기억에만 의존하여 어휘학습이 이루어지는 것으로 나타났다. 이는 어휘발달 지체 아동의 경우 어휘학습에서의 비효율성을 시사하며, 이들 아동에게서 암묵적 학습 능력을 이끌어 내면 좀 더 효율적인 어휘학습 을 가능하게 할 수 있음을 시사한다.

핵심어: 빠른 우연학습, 어휘 학습, 비단어 따라 말하기, 음운단기기억, 학령 전 아동

본 논문은 정부(교육부)의 재원으로 BK21플러스 사업의 지원을 받아수행된 연구임.

\section{참고문헌}

김영태, 홍경훈, 김경희, 장혜성, 이주연(2009). 수용·표현어휘력검사(REVT). 서울: 서울장애인종합복지관.

오다연, 임동선(2013). 2-3세 말 늦은 아동과 정상 아동의 비단어따라말하기와 문장 따라말하기 수행 능력. 언어청각장애연구, 18, 277-287.

김성수(2005). 낱말간 음운적 유사성이 단순언어장애 아동의 빠른 연결(fast-mapping) 수행 전략에 미치는 영향 언어청각장애연구, 10, 25-42.

이효미, 최예린(2011). 일반 아동과 지적장애 아동의 의미단서에 따른 빠른 연결 능력 비교. 언어치료연구, 20, 87-102.

한지연, 정옥란(2000). 단순언어장애 아동과 정상 아동의 빠른 연결(fastmapping)에 대한 비교. 언어치료연구, 9, 23-39.

이현정(2010). 음절길이와 단어유사성이 3-5세 한국어-영어 이중언어아동의 비단어 따라말하기 수행에 미치는 영향. 이화여자대학교 대학원 석사학

위논문.

황보명(2012). 한국어-영어 이중언어 아동과 영어 단일언어 아동의 어휘발달 및 음운단기기억, 이중언어학, 50, 329-352. 